\title{
Efficacy of Panchvalkaladi Oil in the Management of Post- Operative Wound of Breast Abscess: A Single Case Study
}

\section{Gamit N ${ }^{1}$ and Dudhamal TS ${ }^{2 *}$ \\ ${ }^{1} \mathrm{MS}$ (Ayu) S Scholar, India \\ ${ }^{2}$ Department of Shalya Tantra, India}

*Corresponding author: Dudhamal TS, 2Department of Shalya Tantra, IPGT \& RA, GAU, Jamnagar, Gujarat - 361008, India, Tel: +919428671939; Email: dudhamal@ayurveduniversity.com

\section{Case Report \\ Volume 3 Issue 1}

Received Date: March 22, 2019

Published Date: March 29, 2019

DOI: $10.23880 /$ jonam-16000171

\section{Abstract}

Breast abscess occurs in child bearing women during 2-3 weeks of post natal period. The causes may be due to milk engorgement, feeding restriction, infection through duct (Staphylococcus aureus) and sometimes emotional stress. Stana vidradhi can be correlated with Breast abscess basis of symptoms likes tenderness and heaviness in the breast with pain and may also ulceration with thick or yellow pus with fever, thirst, low energy and reduced appetite. In Breast abscess soft tissue are involved and spread infections very fast. Panchvalkaladi oil is having shodhan (cleansing) and ropan (healing) properties and its oil form is being used in Dusta Varna (infected wound). After incision and drainage of breast abscess is infected so in this case Panchvalkaladi oil can be used for management of post operated wound.

Materials \& Method: Patient taken from the Shalyatantra OPD of the I.P.G. T\&R.A hospital, Jamnagar (Gujarat). 24 years old female patient who came with complains of non-healing wound of swelling and pus discharge (breast abscess operated) since last 1 month.The measurement of wound was $O / E 6.8 \times 5.1 \times 5.3 \mathrm{~cm}^{3}$. Wound was cleaned with Normal saline and Panchvalkaladi oil socked gauze was packed in the wound daily once in morning for 8weeks. Along with local management the Amrit kalash-2 tab BD and Avaleha of Amrit kalash one tea Spoon in morning time was continued during the treatment.

Result: After $1^{\text {st }}$ week of dressing, wound became clean and healthy granulation tissue was observed. Wound contraction started after 5 days and wound size reduced remarkable $1 \times 1.3 \times 2.5 \mathrm{~cm}^{3}$ on $6^{\text {th }}$ week and relief all symptoms. Wound completely healed within 8 weeks.

Conclusion: A single case study concluded that Panchvalkaladi oil had healing potential in the management of post operated breast wound.

Keywords: Ayurveda; Breast Abscess; Panchvalakal Oil; Stana Vidradhi; Vrana; Wound 


\section{Journal of Natural \& Ayurvedic Medicine}

\section{Introduction}

A breast abscess is a painful infection brought on by bacteria. The type of bacteria that most frequently produces breast infection is Staphylococcus aurous. An abscess is a hollow space in the breast that becomes filled with Pus from the infected milk ducts. A breast abscess can develop in the presence of severe mastitis [1]. One cross sectional analysis of 89 patients with breast abscesses requiring surgical intervention found that $14 \%$ were lactational and $86 \%$ were non-lactational. In Ayurveda Breast abscess can be co-related with Stana vidradhi given by Acharya sushruta [2]. Herbal and herbomineral formulation are suggested for wound healing in Ayurveda with limited evidence. Acharya Sushruta explained 60 measures for the management of Vrana (wounds), which shows unique therapeutic approach for management of wounds in ancient time [3]. Panchvalkaladi oil indicated in infected wound.

\section{Case Report}

A 24 years old female patient visited in Shalyatantra OPD with complaints of non-healing wound of $6.8 \times 5.1 \times$
$5.3 \mathrm{~cm}^{3}$ lower quadrate right breast with complains of tenderness, slough, and inflamed edges since last 20 days. She had a history of breast abscess and she was under gone off I \& D before 20 days in Ayurveda hospital. Antibiotic, antacid, and analgesic taken for 10 days as prescribed by surgeon. After that there was no improvement in healing of wound. So she came to IPGT \&RA for further management.

\section{Local Examination}

A wound Site is lower quadrate right breast .In inspection seen that Edge and margin Irregular, Floor is cover with slough, Base is Indurate, Surrounding skin is inflamed and reddish. In palpation Regional Lymph node are not enlarged and palpable and tenderness also present. In wound foul odor is present. All routine investigation were done and found under normal limit, there $\mathrm{HB}$ was $10.8 \%$.FBS was $98 \mathrm{mg} / \mathrm{dl}$ and PPBS was $120 \mathrm{mg} / \mathrm{dl}$.

Contain of Panchvalkaladi Oil: Vata, Aswatta, Udumbara, Parish, Plaksha, Nisha, Kadli, Madhuk, Tvak, Sevya, Kustha, Chandana. (Tables 1\& 2) [4].

\begin{tabular}{|c|c|c|c|}
\hline S.NO. & \multicolumn{2}{|c|}{ Name of Ingredient } & Properties \\
\hline 1 & Sanskrit name & Latin name & Varnya, vranropan, vedanasthapana, sothhar, raktasodhak \\
\hline 2 & Vata & Ficus bengalensis linn. & $\begin{array}{c}\text { vranropan, vedanasthapana, sothhar, raktasodhak, } \\
\text { dahaprasamana }\end{array}$ \\
\hline 3 & Udumber & Ficus glomerata roxb. & Varnya, vranropan, vedanasthapana, sothhar, \\
\hline 4 & Parish & Thespesia populenea soland. & Kaphpittasamak, santhaniya, sothhar, kusthahar \\
\hline 5 & Plaksha & Ficus lacor buch. & Raktastrave, sthabhana, sothhar, visrapahar, vranya \\
\hline 6 & Nisha & Curcuma longa.linn & $\begin{array}{c}\text { Sothhar, vedanasthapana, Varnya, kusthaghana, vranasodhana, } \\
\text { vranropan, lekhana }\end{array}$ \\
\hline 7 & Madhuka & Glycyrrhiza glabra.linn & Dahsamak, kesya, vedanasthapana, sothhar \\
\hline 8 & Tvak & Cinnamomnm zeylanicum breyn. & Raktautakleshaka, uttejaka, vedanasthapana, Lekhana \\
\hline 9 & Sevya & Vetiveria zizanioidis linn. & Dahaprasamana, tvagdoshahar, vrnya, swedanayan \\
\hline 10 & Kustha & Saussurea lappa Clarke. & $\begin{array}{c}\text { Durgandhanasana, jantughana, vedanasthapana, vranya, } \\
\text { kusthaghana }\end{array}$ \\
\hline 11 & Chandana & Pterocarpus santalinus linn. & Dahsamak, sthabhana, sothhar, tvagdoshahar \\
\hline 12 & Kadli & Musa acuminate & \\
\hline
\end{tabular}

Table1: Ingredient of panchvalkaladi oil.

\begin{tabular}{|c|c|c|c|}
\hline Kwatha dravyas & Part used & Kalka dravyas & Part used \\
\hline Vata & Tvak & Nisha & Mool \\
\hline Parish & Tvak & Kadli & Tvak \\
\hline Aswatta & Tvak & Madhuk & Tvak \\
\hline Udumbara & Tvak & Sevya & Tvak \\
\hline Plaksha & Tvak & Kustha & Tvak \\
\hline & & Chandana & Tvak \\
\hline
\end{tabular}

Table 2: Ingredients of Panchvalkaladi Oil. 


\section{Journal of Natural \& Ayurvedic Medicine}

\section{Panchvalkaladi Oil Preparation [5]}

Kwatha was prepared by taking 8 times of water to kwathya dravyas and reducing up to $1 / 4^{\text {th }}$ part. It was filtered through cotton cloth. Tila taila was taken in stainless steel vessels and placed over mild heat. When fumed started appear kalka was added. Soon after kwatha was added in to it and boiled with frequent stirring, maintaining mild temperature. Paka was continued till sneha paka lakshana were appeared. Then, it was filtered in warm condition through cotton cloth and allowed for self-cooling .Lastly it was stored in airtight container.

\section{Observation \& Results}

Patient was treated with local application of Panchvalkaladi oil daily and observed for improvement at regular intervals. The wound was cleaned with normal saline and surrounding area with Betadine solution and
Panchvalkaladi oil was applied on wound in sufficient quantity then wound was covered with sterile gauze and bandaged with micropore. Changes in symptoms tenderness, color, inflammation, slough, size of wound, etc. observed, after $7^{\text {th }}$ days of the application of oil the slough from the wound got removed by itself, inflammation of edges and redness also decreased, sized wound remained $4.5 \times 4.0 \times 3.5 \mathrm{~cm}^{3}$. There was fresh granulation tissue at base without any swelling, redness, slough. After $15^{\text {th }}$ days, fresh contracting white margins appeared as a sign of wound healing. The wound base filling with vascularized tissues and healthy granulation seen on the wound surface. After the $30^{\text {th }}$ days of treatment wound sized was $2.2 \times 2.0 \times 2.5 \mathrm{~cm}$. Tablet mahrashi amrita kalash BD for 30 days was prescribed and mahrashi amrita kalash Avaleha $50 \mathrm{gm}$ at morning with warm water taken for 30 days. After 45 days of Panchvalkaladi Oil dressing wound was completely healed (Figure 1).

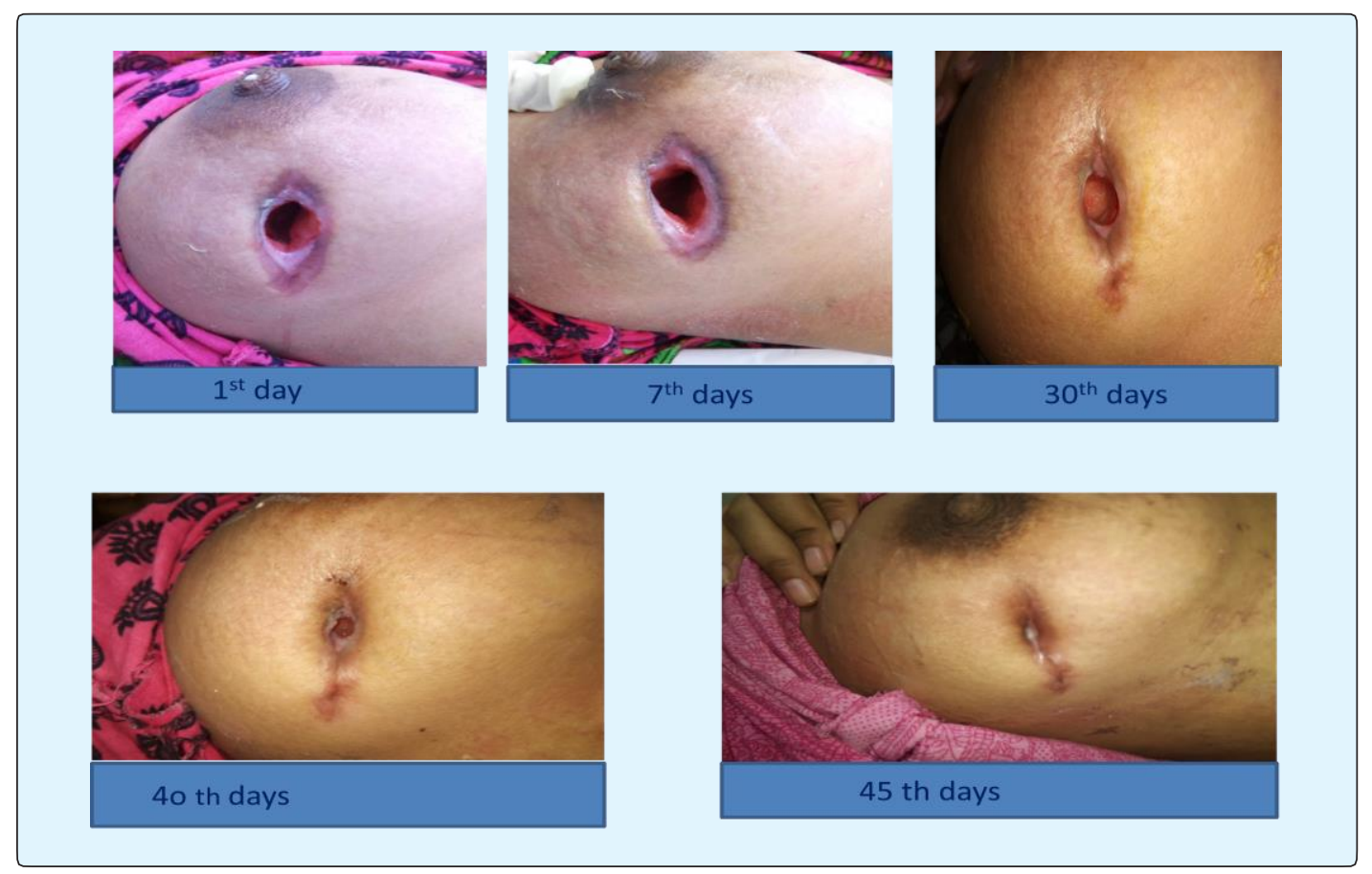

\section{Discussion}

- Vata: Sushruta Samhita a decocation of the fruits is recommended for washing of wound for quick healing, Fruit extract exhibited significant antibacterial activity [6].

- Yastimadhu: Sushruta Samhita promoting growth of healthy tissue after surgery and promoting oadhesion of operated tissues.Glycyrrhizinic acid show in vitro antimicrobial action again staphylo coccous, myobactrium etc [7] . Glycyrrhizin proved to be used adjuant drug in the treatment of severe fungal infection [8]. Flavonoids liquiritin \& genin liquiritigenin also display anti inflammatory action [9].

- Chandana: As per Sushruta Samhita wood preparation are useful in treatment of wound,burn,nonn-healing ulcer ,Sandal wood oil inhibition of replication of herpus simple virus 1 and 2 [10].

- Kushtha: Ethanol extract of roots show antiinflammatory and anti-arthritic activity [11].

- Curcuma longa: Sushruta Samhita is used for cleaning and sterilizing the interior of an ulcer. Curcuminoids 


\section{Journal of Natural \& Ayurvedic Medicine}

and the essential oil, display useful anti-inflammatory action [12]. Curcuminoids exhibit antimicrobial activity, essential oil has significant antibacterial action against gram-positive and gram negative bacteria and anti-fungal against yeasts [13].

- Musa acuminate: The Methanol extract of Musa acuminate bract showed good pharmacological activity against gram-positiva and gram negative bacteria [14].

\section{Panchvalkal Rasa Panchak and its Activity [15]}

RASA: Considering the mode of action by the Rasa, Panchvalakal must have been Vatakara and hence increase the Ruja (pain) which is predominantly due to Vata. But the effect of the drug on Ruja is found to be highly significant. This might due to the action of the Guna (Property). Having Guru (heavy) Guna it is supposed to be Vatahara and thus might have decreased the Ruja.

Panchvalakal is a drug with Kashaya Rasa (astringent taste) and by the action of the Rasa; it acts as a Stambhaka (arresting) and Grahi (that holds). It also must be Atitwak Prasadaka (cleanses the skin and removes all the dirt from here). Due to all these properties, it must have reduced the Strava (discharge). The drug is Rooksha (dry) and Kaphahara. Moreover the Lekhana (scraping), Kledahara (arresting Dampness), Chedana (destroying/removing) and Raktashodhaka (blood purifier) properties of Kashaya Rasa also will facilitate the debridement of the slough.

In case of Panchvalakal, which is considered to be good Shothahara (that which reduces swelling), due to the Kashaya Rasa of the drug it acts with Peedana (act of squeezing), Ropan (heal) and Shodhana (curative effect) property. Due to these properties, it destroys or liquefies the accumulated substances and hence minimizes the swelling.

\section{Veerya}

The Stambhan effect might also be attributed to the Sheeta Veerya (cold in potency) of the drugs. Panchvalakal are considered to be Pittaghna, that is both by the action of Rasa (taste) and Veerya (potency) they are Pittahara and therefore they must decrease the Raga (redness), which is mainly due to Pitta.

\section{Conclusion}

A single case study concluded that Panchvalkaladi oil has potential in the management of big size wound this observation needs to be studied in more patients to explore better options for non-healing wound too.

\section{References}

1. https://www.ncbi.nlm.nih.gov>books

2. Shastri KA (2014) Susruta Samhita, edited with Ayurveda tattvasandipika-hindicommentary, scientific analysis, notes. Chaukhambha sanskrit sansthan, publisher and distributer of oriental culture, varnasi, India, pp: 103.

3. Shastri KA (2014) Susruta Samhita, edited with Ayurveda tattvasandipika-hindicommentary, scientific analysis, notes. chaukhambha sanskrit sansthan, publisher and distributer of oriental culture literature varnasi, India, pp: 5.

4. Sharma R (2004) Chaukhambha Sanskrit pratisthan, javaharnager, India, pp: 82.

5. Murthy KRS (2003) chaukhambha oriental, $5^{\text {th }}$ (Edn.), varnasi, India, pp: 116-117

6. Dev S (2006) Prime Ayurvedic plant drugs, ANAMAYA publisher. J Ethnopharmacol 60: 85.

7. Dev S (2006) Prime Ayurvedic plant drugs, ANAMAYA publisher India, 1: 304.

8. Dev S (2006) Prime Ayurvedic plant drugs, ANAMAYA publisher India. Abster Chin Med 5(2): 80.

9. Dev S (2006) Prime Ayurvedic plant drugs, ANAMAYA publisher, India, pp: 195.

10. Dev S (2006) Prime Ayurvedic plant drugs, ANAMAYA publisher, India $\mathrm{F}$ Benencia, (Edd.), MC Courreges, phytomedicine 6: 119.

11. Dev S (2006) Prime Ayurvedic plant drugs, ANAMAYA publisher India. In $\mathrm{H}$ Matsuda, et al. (Eds.), Bioorg Med Chem Arch Pharm Res 23: 54.

12. Dev S (2006) Prime Ayurvedic plant drugs, ANAMAYA publisher India. Wah Plant Med 57: 1.

13. Dev S (2006) Prime Ayurvedic plant drugs. ANAMAYA publisher India Martins AP, et al. (Eds.), Planta Med 67: 580 .

14. https://irjponline.com>php

15. https://www.ncbi.nlm.nih.gov>articles

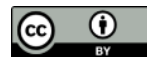

